Article

\title{
Influence of Bi chemical state on the photocatalytic performance of Bi-doped $\mathrm{NaTaO}_{3}$
}

\author{
Huanan Cui, Jianying Shi*, Hong Liu \# \\ Key Laboratory of Environment and Energy Chemistry of Guangdong Higher Education Institutes, School of Chemistry and Chemical Engineering, \\ Sun Yat-sen University, Guangzhou 510275, Guangdong, China
}

A R T I C L E I N F 0

Article history:

Received 29 December 2014

Accepted 28 March 2015

Published 20 July 2015

\section{Keywords:}

Photocatalyst

Sodium tantalum oxide

Bi doping

Chemical state

Water splitting

\begin{abstract}
A B S T R A C T
$\mathrm{NaBiO}_{3}$ and $\mathrm{Bi}\left(\mathrm{NO}_{3}\right)_{3}$ were used to synthesize Bi-doped $\mathrm{NaTaO}_{3}$. The influence of the Bi chemical state on the photocatalytic activity was investigated using X-ray diffraction, Raman spectroscopy, X-ray photoelectron spectroscopy (XPS) and diffused reflectance spectroscopy to study the structure, chemical state and light absorption characteristics, respectively. The photocatalytic activity was evaluated by the $\mathrm{H}_{2}$ evolution water splitting reaction. The monoclinic phase of $\mathrm{NaTaO}_{3}$ remained intact for the two Bi-doped samples, but the Ta-O-Ta bond was distorted from $180^{\circ}$ after $\mathrm{Bi}$ doping. XPS results indicated that $\mathrm{Bi}^{3+}$ was doped into $\mathrm{NaTaO}_{3}$ with the $\mathrm{Bi}\left(\mathrm{NO}_{3}\right)_{3}$ precursor, while $\mathrm{Bi}^{5+}$ and $\mathrm{Bi}^{3+}$ were doped into $\mathrm{NaTaO}_{3}$ with the $\mathrm{NaBiO}_{3}$ precursor. The two samples showed identical light absorption, where doping with Bi extended the light absorption to long wavelength light as expected. However, $\mathrm{Bi}^{3+}$ doping did not promote the photocatalytic activity of $\mathrm{NaTaO}_{3}$, while $\mathrm{Bi}^{5+}$ and $\mathrm{Bi}^{3+}$ doping did. The distorted $\mathrm{Ta}-\mathrm{O}-\mathrm{Ta}$ bond from $180^{\circ}$ due to doping with $\mathrm{Bi}$ was detrimental for charge carrier transfer in the photocatalytic process. In contrast, the vacancies or defects in the $\mathrm{NaTaO}_{3}$ lattice induced by $\mathrm{Bi}$ doping for charge balance were beneficial for charge carrier separation. The opposing action of these two factors resulted in the activity of the $\mathrm{Bi}^{3+}$-doped sample being comparable with pristine $\mathrm{NaTaO}_{3}$. For $\mathrm{Bi}^{5+}$ - and $\mathrm{Bi}^{3+}$-doped $\mathrm{NaTaO}_{3}$, a high concentration of defects was induced by the high valence $\mathrm{Bi}^{5+}$ ion and this led to its higher photocatalytic activity. Our results indicated that charge carrier transfer is a priority factor in the photocatalytic process and the doping of a high valence ion in the $\mathrm{ABO}_{3}$ structure is a way to promote the separation of charge carriers.
\end{abstract}

(C) 2015, Dalian Institute of Chemical Physics, Chinese Academy of Sciences. Published by Elsevier B.V. All rights reserved.

\section{Introduction}

The photocatalytic water splitting reaction has been extensively studied as a conversion system to solve the energy issues nowadays [1,2]. A series of oxides with the $\mathrm{ABO}_{3}$ perovskite structure (e.g. $\mathrm{NaTaO}_{3}$ [2], $\mathrm{AgTaO}_{3}$ [3], $\mathrm{KNbO}_{3}$ [4], $\mathrm{CaTiO}_{3}$ [5], and $\mathrm{SrTiO}_{3}$ [6]) have been found to be highly active photocatalysts [7]. The ideal structure of the perovskite-type oxides
$\left(\mathrm{ABO}_{3}\right)$ is a network of corner-linked octahedra. The $\mathrm{B}$ cations are located at the center of the octahedra ([BO6] $]$ ) and the A cations are in the space coordinating with 12 oxygen atoms between the octahedra ( $\left.\left[\mathrm{AO}_{12}\right]\right)$. The $\left[\mathrm{BO}_{6}\right]$ octahedra is usually used for energy band construction when $d^{0} / d^{10}$ transition metal ions are the B-site [7]. For instance, it is believed that in $\mathrm{ATaO}_{3}$ and $\mathrm{ANbO}_{3}(\mathrm{~A}=\mathrm{Na}$ and $\mathrm{K})$, the valence band is formed by the $02 p$ orbital and the conduction band is formed by Ta $5 d$

\footnotetext{
* Corresponding author. Tel: +86-20-84114227; E-mail: shijying@mail.sysu.edu.cn

\# Corresponding author. Tel: +86-20-84115573; Fax: +86-20-84110927; E-mail: ceshliu@mail.sysu.edu.cn

This work was supported by the National Natural Science Foundation of China (21103235) and the Science and Technology Program of Guangzhou City (2013J4100110).

DOI: 10.1016/S1872-2067(15)60858-0 | http://www.sciencedirect.com/science/journal/18722067 | Chin. J. Catal., Vol. 36, No. 7, July 2015
} 
and $\mathrm{Nb} 4 d$ orbital [8].

Although the $\mathrm{ABO}_{3}$ perovskites are well known as promising photocatalysts in solar energy utilization, they still suffer from the problems of a restricted light response and highly inhibited photo-generated carrier activity. Doping a foreign element is a usual strategy to solve these problems and improve the photocatalytic performance $[9,10]$. In previous reports, visible light activity was observed when $\mathrm{V}^{5+}$ was substituted for $\mathrm{Ta}^{5+}$ in $\mathrm{NaTaO}_{3}$ samples to extend the light response [11]. Doping $\mathrm{Cu}^{2+}$ at the B-site in $\mathrm{NaTaO}_{3}$ also extended the light response, but excess $\mathrm{Cu}^{2+}$ would serve as a recombination center, which decrease the photocatalytic activity [12]. However, $\mathrm{Zr}^{4+}$ doping at the B-site mainly affected the behavior of the charge carriers instead of the energy band structure in $\mathrm{KTaO}_{3}$ [4]. The A-site substitution can also influence the perovskite photocatalytic activity. Hwang's group [13] found in $\mathrm{La}_{x} \mathrm{Na}_{1-x} \mathrm{TaO}_{3}$ samples that doping of La at the A-site caused little variation in the energy band structure, and the change in $\mathrm{H}_{2}$ evolution rate was attributed to better charge carrier separation and migration. Similar results were also reported for $\mathrm{Na}_{1-x} \mathrm{~K}_{x} \mathrm{TaO}_{3}$ [14] and another $\mathrm{NaTaO}_{3}$ :La sample [15].

The type of doped ion (e.g. alkali ions [14], alkaline earth ions [16], and lanthanides [17]), position of the doped ion (Aor B-sites) and the valence state of the doped ion in the perovskite are all factors that can affect the photocatalytic performance [18]. However, the function of the doped ion in the perovskite is still debated, and it is harder to discriminate the function of the doped ion when co-doping multi-valence metal ions into both $\mathrm{A}$ - and $\mathrm{B}$-sites of $\mathrm{ABO}_{3}$ [19-26]. The physicochemical properties of the material are significantly altered by the accommodating site and the valence state of the doped cation. Hence, it is necessary to precisely control the occupation site and valence state of the doped ion in the $\mathrm{ABO}_{3}$ structure to clarify its function in photocatalysis.

In this work, $\mathrm{NaBiO}_{3}$ and $\mathrm{Bi}\left(\mathrm{NO}_{3}\right)_{3}$ were used as the Bi precursor to synthesize $\mathrm{Bi}$-doped $\mathrm{NaTaO}_{3}$ with different $\mathrm{Bi}$ chemical states, and the influence of the Bi ion chemical state on the photocatalytic activity was investigated. It was found that Bi doping mainly influenced charge carrier transfer in the photocatalytic process, and a high valence state ion dopant benefits defect generation to promote the separation of charge carriers.

\section{Experimental}

\subsection{Materials and synthesis}

$\mathrm{Ta}_{2} \mathrm{O}_{5}(>99 \%)$ was purchased from Aladdin Industrial Corporation (USA). The other reagents (analytically pure) were purchased from Guangzhou Chemical Reagent Factory. All reagents were used as received without further purification. Double distilled water was used in all experiments.

A solid state reaction was used to synthesize pristine and Bi-doped $\mathrm{NaTaO}_{3} \cdot \mathrm{NaBiO}_{3} \cdot 2 \mathrm{H}_{2} \mathrm{O}$ and $\mathrm{Bi}\left(\mathrm{NO}_{3}\right)_{3} \cdot 5 \mathrm{H}_{2} \mathrm{O}$ were used as the $\mathrm{Bi}$ source for $\mathrm{Bi}$ doping of the $\mathrm{NaTaO}_{3}$ samples. A typical solid state reaction is described in the following. A mixture of the starting materials of $\mathrm{Ta}_{2} \mathrm{O}_{5}, \mathrm{Na}_{2} \mathrm{CO}_{3}$, and $\mathrm{Bi}$ source was pressed into pellets, calcined in air at $1000{ }^{\circ} \mathrm{C}$ for $10 \mathrm{~h}$ and then ground into fine powder. The powder was washed with distilled water, then filtered and dried at $120^{\circ} \mathrm{C}$ for use. The molar ratio of $\mathrm{Na}$ Ta:Bi was 1.05:1:0.02 in the starting mixture of $\mathrm{Na}_{2} \mathrm{CO}_{3}, \mathrm{Ta}_{2} \mathrm{O}_{5}$, and $\mathrm{Bi}$ precursor, where the $5 \%$ excess $\mathrm{Na}$ was to compensate the volatilization loss. The samples were denoted as V-0.02 and III-0.02, where V and III showed the valence state of the Bi source, and 0.02 is from the Bi:Ta ratio.

For comparison, Bi-doped $\mathrm{NaTaO}_{3}$ with 0.02 molar ratio of Bi to Ta was prepared by the hydrothermal method based on the literature [25]. First, the starting materials of $\mathrm{Ta}_{2} \mathrm{O}_{5}$ and $\mathrm{NaBiO}_{3} \cdot 2 \mathrm{H}_{2} \mathrm{O}$ were dispersed in $\mathrm{NaOH}$ aqueous solution $(10$ mol/L) by strong stirring for $2 \mathrm{~h}$. Then, the slurry was poured into a Teflon-lined autoclave and heated at $180{ }^{\circ} \mathrm{C}$ for $48 \mathrm{~h}$. After filtering and washing, the resulting powder was dried at $120{ }^{\circ} \mathrm{C}$ to get the final product. In this method, excess $\mathrm{Na}$ ion was introduced by a strong base. The sample was denoted as HV-0.02 $\mathrm{NaTaO}_{3}$.

\subsection{Characterization}

The crystal structure of the samples was analyzed by an X-ray diffractometer (XRD, Bruker, D8 Advance, Germany) with a $\mathrm{Cu} K_{\alpha}$ radiation source at a scanning rate of $10^{\circ} / \mathrm{min}$ for all samples. Raman spectra were measured with a Laser Micro-Raman Spectrometer (Renishaw inVia) with a $\mathrm{Ar}^{+}$laser with $633 \mathrm{~nm}$ excitation. The chemical environment of doped Bi was studied by X-ray photoelectron spectroscopy (XPS, Kratos Axis Ultra XPS, ESCALab250, American; hemispherical electron analyser, $120 \mathrm{~W}$ Al $K_{\alpha} \mathrm{X}$-ray source, $h v 1486.6 \mathrm{eV}$ ). The C $1 s$ reference of $284.1 \mathrm{eV}$ was chosen for calibration. Diffuse reflection spectra (DSR) were recorded on a UV-Vis spectrophotometer (Shimadzu, UV-3150, Japan, equipped with an integrating sphere) to study the optical properties of the samples.

\subsection{Photocatalytic evaluation}

The photocatalytic activity of the samples was examined in a closed gas circulation and evacuation system. Typically, $0.1 \mathrm{~g}$ catalyst powder was dispersed in $100 \mathrm{~mL}$ methanol aqueous solution (20 vol\%) in a Pyrex reaction cell. Pt was photodeposited on the catalyst with $0.3 \mathrm{wt} \%$ loading in situ using a $\mathrm{H}_{2} \mathrm{PtCl}_{6} \cdot 6 \mathrm{H}_{2} \mathrm{O}$ precursor under irradiation. The light source was a $300 \mathrm{~W}$ Xe lamp (Beijing Changtuo, PLS-SXE-300UV) with an intensity of $200 \mathrm{~mW} / \mathrm{cm}^{2}$. The light absorption spectra were shown elsewhere [27]. The amount of produced hydrogen was analyzed using an online gas chromatograph (Shanghai Tianmei, GC-7890II, China) with a thermal conductivity detector and a molecular sieve $5 \mathrm{~A}$ column and $\mathrm{N}_{2}$ carrier.

\section{Results and discussion}

\subsection{Crystal structure of Bi doped $\mathrm{NaTaO}_{3}$}

Figure 1 shows the XRD patterns of the $\mathrm{NaTaO}_{3}$ and Bi-doped $\mathrm{NaTaO}_{3}$ samples. The XRD pattern of $\mathrm{NaTaO}_{3}$ was in agreement with PDF \#74-2480 (P2/m with $a=c=0.3907 \mathrm{~nm}, b$ $=0.3904 \mathrm{~nm}$, and $\alpha=\gamma=90^{\circ}, \beta=90.1^{\circ}$ ), and indicated the crys- 


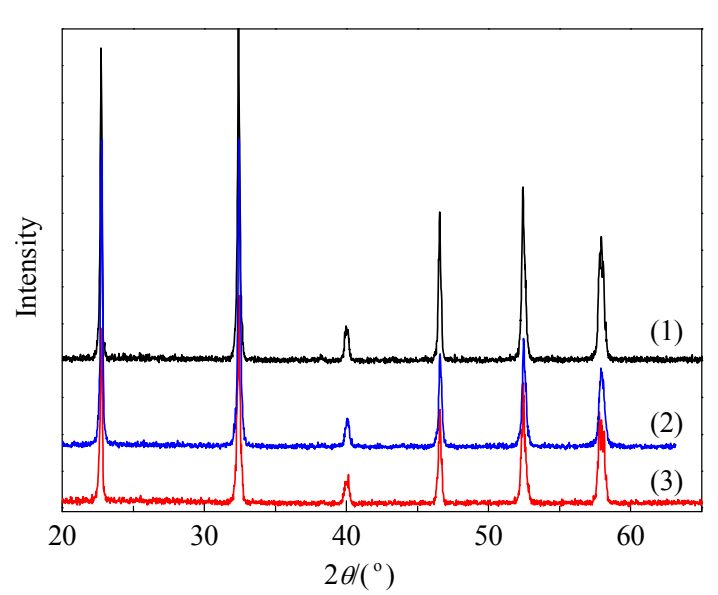

Fig. 1. XRD patterns of $\mathrm{NaTaO}_{3}(1), \mathrm{V}-0.02 \mathrm{NaTaO}_{3}(2)$ and III-0.02 Na$\mathrm{TaO}_{3}(3)$.

tal structure to be the monoclinic phase. For the Bi-doped Na$\mathrm{TaO}_{3}$ samples, the diffraction patterns were similar to pristine $\mathrm{NaTaO}_{3}$, and no additional peak was detected. This suggested that the monoclinic phase of $\mathrm{NaTaO}_{3}$ remained intact and no impurity existed in $\mathrm{Bi}$-doped $\mathrm{NaTaO}_{3}$. It was reported that the $\mathrm{Na} / \mathrm{Ta}$ molar ratio of the starting materials affects the site occupancy of $\mathrm{Bi}$ at the $\mathrm{A}$ - or $\mathrm{B}$-site in the $\mathrm{NaTaO}_{3}$ lattice, and $\mathrm{Bi}$ predominantly occupied the Na-site under a Na-deficient condition [24]. In our case, though 5\% excess Na ion was introduced in the synthesizing process, the Na:Ta molar ratio in pristine $\mathrm{NaTaO}_{3}$ was 1:1.9 from the quantitative analysis by XPS. Thus, it was proposed that the Bi ion was located at the A site because of the low $\mathrm{Na} / \mathrm{Ta}$ ratio.

\subsection{Raman spectra}

Figure 2 shows the Raman spectra of the $\mathrm{NaTaO}_{3}$ and Bi-NaTaO ${ }_{3}$ samples. Two distinct peaks at 578 and $860 \mathrm{~cm}^{-1}$ were observed for both the V-0.02 and III-0.02 samples, which were absent from pristine $\mathrm{NaTaO}_{3}$. These two peaks corresponded to the Stokes-shifted signals from the transverse and longitudinal optical phonons [28]. The appearance of these two

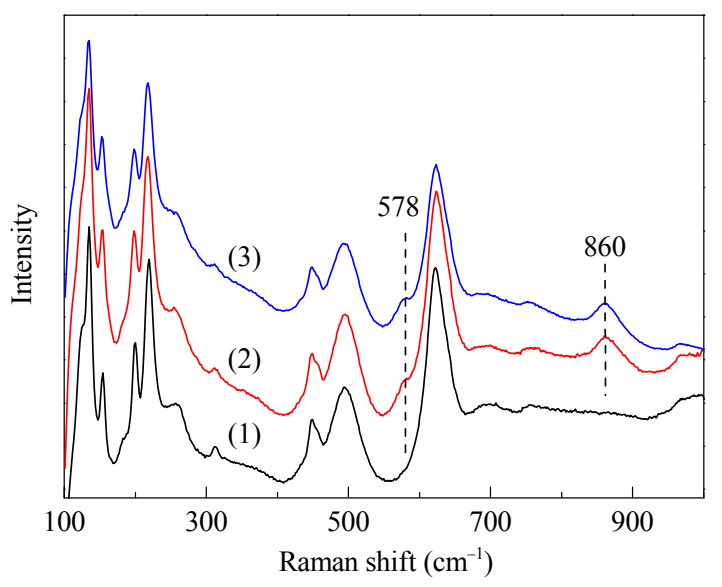

Fig. 2. Raman spectra of $\mathrm{NaTaO}_{3}(1), \mathrm{V}-0.02 \mathrm{NaTaO}_{3}(2)$ and III-0.02 $\mathrm{NaTaO}_{3}(3)$. peaks indicated that $\mathrm{Bi}$ ion doping induced a band gap change in $\mathrm{NaTaO}_{3}$ [29].

In addition to the energy band structure, Raman spectroscopy of solids is extremely sensitive to the local deviation from the average periodicity, thereby making it a valuable probe of the local structure. The region of 850 to $950 \mathrm{~cm}^{-1}$ was assigned to the valence vibrations of the Ta-0-Ta bridges that were inactive in the Raman spectra for the centrosymmetric structure [30]. The appearance of $860 \mathrm{~cm}^{-1}$ for Bi-doped $\mathrm{NaTaO}_{3}$ indicated a distorted $\mathrm{B}-\mathrm{O}-\mathrm{B}$ bond from the bond angle of $180^{\circ}$, which has an impact on the photo-induced charge carrier migration in the photocatalyst [14].

\subsection{Chemical state of $\mathrm{Bi}$ in $\mathrm{NaTaO}_{3}$}

The chemical environment and oxidation state of $\mathrm{Bi}$ in Na$\mathrm{TaO}_{3}$ were studied by X-ray photoelectron spectroscopy (XPS). Figure 3 shows XPS spectra of the samples. The Bi $4 f_{7 / 2}$ and $4 f_{5 / 2}$ peaks were at 158 and $164 \mathrm{eV}$, respectively. For comparison, the XPS spectra of $\mathrm{Bi} 4 f$ in $\mathrm{Bi}_{2} \mathrm{O}_{3}, \mathrm{NaBiO}_{3}, \mathrm{BiTaO}_{4}$ and HV-0.02 (synthesized with the hydrothermal method) were also measured to deduce the position and valence state information of the doped $\mathrm{Bi}$ ion. The binding energy (BE) of $\mathrm{Bi} 4 f_{7 / 2}$ for all the samples is summarized in Table 1.

In the reference samples, $\mathrm{Bi}_{2} \mathrm{O}_{3}$ and $\mathrm{NaBiO}_{3}$ were the precursors of $\mathrm{Bi}$ with the +3 and +5 chemical valence, respectively. The $\mathrm{BE}$ positions of $\mathrm{Bi} 4 f_{7 / 2}$ in $\mathrm{Bi}_{2} \mathrm{O}_{3}$ and $\mathrm{NaBiO}_{3}$ were 158.3 and $158.8 \mathrm{eV}$, respectively, and the $0.5 \mathrm{eV}$ chemical shift was ascribed to the oxidation state difference. For $\mathrm{BiTaO}_{3}$ with the perovskite structure, the $\mathrm{Bi}$ ion is located at the A-site with +3

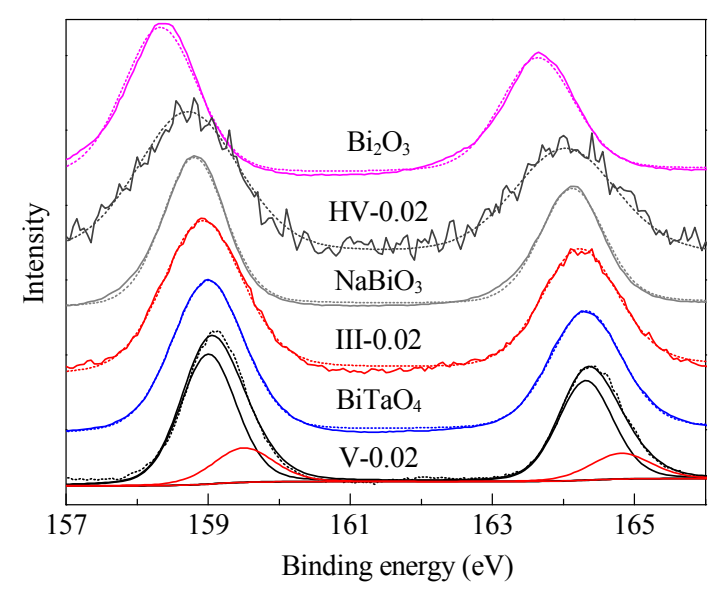

Fig. 3. XPS spectra of $\mathrm{Bi} 4 f_{7} / 2$ and $\mathrm{Bi} 4 f_{5 / 2}$ of $\mathrm{Bi}_{2} \mathrm{O}_{3}, \mathrm{HV}-0.02 \mathrm{NaTaO}_{3}$, $\mathrm{NaBiO}_{3}$, III-0.02 $\mathrm{NaTaO}_{3}, \mathrm{BiTaO}_{4}$ and V-0.02 $\mathrm{NaTaO}_{3}$.

\section{Table 1}

Bi $4 f_{7} / 2$ binding energy of $\mathrm{Bi}_{2} \mathrm{O}_{3}, \mathrm{HV}-0.02 \mathrm{NaTaO}_{3}, \mathrm{NaBiO}_{3}, \mathrm{III}-0.02 \mathrm{Na}-$ $\mathrm{TaO}_{3}, \mathrm{BiTaO}_{4}$ and V-0.02 $\mathrm{NaTaO}_{3}$.

\begin{tabular}{lc}
\hline Sample & Binding energy of Bi $4 f_{2 / 7}(\mathrm{eV})$ \\
\hline $\mathrm{V}-0.02 \mathrm{NaTaO}_{3}$ & $159.0,159.5$ \\
$\mathrm{III}-0.02 \mathrm{NaTaO}_{3}$ & 158.9 \\
$\mathrm{BiTaO}_{4}$ & 159.0 \\
$\mathrm{NaBiO}_{3}$ & 158.8 \\
$\mathrm{Bi}_{2} \mathrm{O}_{3}$ & 158.3 \\
$\mathrm{HV}_{-}-0.02 \mathrm{NaTaO}_{3}$ & 158.7 \\
\hline
\end{tabular}


chemical valence. The $\mathrm{BE}$ position of $\mathrm{BiTaO}_{3}$ was $159.0 \mathrm{eV}$, which was higher than $158.3 \mathrm{eV}$ for $\mathrm{Bi}^{3+}$ in $\mathrm{Bi}_{2} \mathrm{O}_{3}$ and $158.8 \mathrm{eV}$ for $\mathrm{Bi}^{5+}$ in $\mathrm{NaBiO}_{3}$. This suggested that the $\mathrm{Bi}$ chemical environment exhibited more influence on its $\mathrm{BE}$ than its oxidation state, and the A-site Bi substitution for $\mathrm{Na}$ can significantly increase the BE.

For HV-0.02 $\mathrm{NaTaO}_{3}$, the $\mathrm{Bi}$ ion is located at the B-site in $\mathrm{NaTaO}_{3}$ with the +5 chemical valence [25]. HV-0.02 $\mathrm{NaTaO}_{3}$ was synthesized by the hydrothermal method with the strong base of sodium hydroxide, where the low hydrothermal temperature avoided the decomposition of $\mathrm{NaBiO}_{3}$ to $\mathrm{Bi}^{3+}$ and excess sodium ion in the strong base made the $\mathrm{Bi}^{5+}$ substituted for $\mathrm{Ta}^{5+}$ at the B-site in $\mathrm{NaTaO}_{3}$. The position of the BE in HV-0.02 $\mathrm{NaTaO}_{3}$ was $158.7 \mathrm{eV}$, which was comparable to the $158.8 \mathrm{eV}$ for $\mathrm{Bi}^{5+}$ in $\mathrm{NaBiO}_{3}$. Thus, it was proposed that the $\mathrm{B}$-site $\mathrm{Bi}$ substitution for $\mathrm{Ta}$ in $\mathrm{NaTaO}_{3}$ had little impact on the $\mathrm{BE}$ position of the Bi ion.

For the III-0.02 $\mathrm{NaTaO}_{3}$ sample synthesized with the $\mathrm{Bi}_{2} \mathrm{O}_{3}$ precursor, the position of the $\mathrm{BE}$ was $158.9 \mathrm{eV}$, which was close to $159.0 \mathrm{eV}$ for $\mathrm{Bi}^{3+}$ at the A-site in $\mathrm{BiTaO}_{3}$. Therefore, it was deduced that $\mathrm{Bi}^{3+}$ substituted for $\mathrm{Na}^{+}$at the A-site in the III-0.02 sample. For the V-0.02 sample synthesized with the $\mathrm{NaBiO}_{3}$ precursor, the BE position was higher than for III-0.02 in Fig. 3. Due to the pyrolysis of $\mathrm{NaBiO}_{3}$, it was reasonable that $\mathrm{Bi}^{3+}$ and $\mathrm{Bi}^{5+}$ would coexist in the V-0.02 sample under the high temperature synthesis condition. Therefore, the XPS curve of V-0.02 was fit by two peaks with the BE positions at 159.0 and 159.5 $\mathrm{eV}$. The lower $\mathrm{BE}$ at $159.0 \mathrm{eV}$ was the same as the $\mathrm{BE}$ for $\mathrm{Bi}^{3+}$ at the $\mathrm{A}$-site in $\mathrm{BiTaO}_{3}$, therefore, this peak was identified as the $\mathrm{Bi}^{3+}$ substitution for $\mathrm{Na}$ in the $\mathrm{V}-0.02$ sample. For the other peak at $159.5 \mathrm{eV}$ in $\mathrm{V}-0.02$, three possible assignments should be taken into account. First is the A-site $\mathrm{Bi}^{5+}$ substitution for $\mathrm{Na}$ in $\mathrm{V}-0.02$, second is the $\mathrm{B}$-site $\mathrm{Bi}^{5+}$ substitution for $\mathrm{Ta}$ in $\mathrm{V}-0.02$, and third is the $\mathrm{Bi}^{3+}$ in a different chemical environment reported in a previous work [31].

In the above paragraph, it was discussed that the $\mathrm{BE}$ of $\mathrm{Bi}^{5+}$ substitution for Ta in HV-0.02 was $158.7 \mathrm{eV}$, which is far lower than $159.5 \mathrm{eV}$. So the second possibility of the B-site $\mathrm{Bi}^{5+}$ substitution for Ta was excluded. Based on the BE difference of $\mathrm{Bi}_{2} \mathrm{O}_{3}$ and III-0.02 ( $\mathrm{Bi}^{3+}$ in A-site), and of $\mathrm{NaBiO}_{3}$ and HV-0.02 $\left(\mathrm{Bi}^{5+}\right.$ in $\mathrm{B}$-site), it was proposed that the A-site substitution can more significantly increase the $\mathrm{BE}$ of the $\mathrm{Bi}$ ion than the $\mathrm{B}$ site, and the chemical environment had a more significant influence on the $\mathrm{BE}$ than the oxidation state. For $\mathrm{Bi}^{3+}$ in a different chemical environment proposed in the literature [31], the BE should not be as high as $159.5 \mathrm{eV}$, considering its +3 oxidation state and that the chemical environment was different from the A-site. That is, the third possibility of $\mathrm{Bi}^{3+}$ in a different chemical environment was also excluded. Therefore, we assigned the $159.5 \mathrm{eV}$ peak to the A-site $\mathrm{Bi}^{5+}$ substitution for $\mathrm{Na}$ from an overall consideration of the chemical states. This remains to be further explored in future work.

Thus, we identified that the $\mathrm{Bi}^{3+}$ doping occurred at the A-site in the III-0.02 sample, while $\mathrm{Bi}^{3+}$ and $\mathrm{Bi}^{5+}$ co-doping at the A-site occurred in the V-0.02 sample. It was worth mentioning that the $\mathrm{Bi}^{5+}$ content in $\mathrm{V}-0.02$ was far smaller than $\mathrm{Bi}^{3+}$ from the two components of the XPS fitting in Fig. 3. That is, most of $\mathrm{NaBiO}_{3}$ was pyrolysed to $\mathrm{Bi}^{3+}$, and only a small amount of $\mathrm{Bi}^{5+}$ was doped into the $\mathrm{NaTaO}_{3}$ cell. The $\mathrm{Bi}^{3+}$ and $\mathrm{Bi}^{5+}$ co-existence in $\mathrm{NaTaO}_{3}$ induced the production of $\mathrm{Na}$ vacancies or interstitial $\mathrm{O}$ atoms in the lattice for charge compensation, which will have an impact on the photocatalytic process and interstitial charge migration [23].

\subsection{Optical absorption of $\mathrm{Bi}$-doped $\mathrm{NaTaO}_{3}$}

Diffused reflectance spectra of pristine and Bi-doped Na$\mathrm{TaO}_{3}$ samples are shown in Fig. 4. The steep edges and intense absorption of $\mathrm{NaTaO}_{3}$ originated from the transition from the valence band to the conduction band. A shoulder peak on the steep absorption edge of $\mathrm{NaTaO}_{3}$ was observed in the Bi-doped V-0.02 and III-0.02 samples, which indicated that doped Bi ions extended the absorption edge to a longer wavelength. The valence band (VB) was mainly composed of $02 p$ orbitals while the conduction band (CB) mainly consists of Ta $5 d$ orbitals for $\mathrm{NaTaO}_{3}$ [18]. This shoulder peak in the absorption spectra can be attributed to the transition from the localized impurity state of the Bi ion dopant. An isolated donor energy state was formed in the forbidden band of $\mathrm{NaTaO}_{3}$ during $\mathrm{Bi}$ doping, from considering the energy structure of $\mathrm{BiTaO}_{4}$ [32].

\subsection{Photocatalytic $\mathrm{H}_{2}$ generation}

The photocatalytic activity of pristine and $\mathrm{Bi}$-doped $\mathrm{NaTaO}_{3}$ samples were examined by splitting water into $\mathrm{H}_{2}$ under simulated solar light. For all samples, $\mathrm{H}_{2}$ generation was linear with irradiation time as shown in Fig. 5. The highest activity was observed for the V-0.02 sample, and the photocatalytic activity of the III-0.02 sample was comparable with that of $\mathrm{NaTaO}_{3}$.

In the absorption spectra, almost similar absorption profiles were observed for the V-0.02 and III-0.02 samples. The photocatalytic activity distinctly increased with the V-0.02 sample, but remained unchanged with III-0.02. Due to the low Bi ion content in $\mathrm{NaTaO}_{3}$, the slight extending of light absorption to the visible region contributed little to the photocatalytic activity. In addition to light absorption for charge carrier generation, charge transfer inside the photocatalyst is an important factor

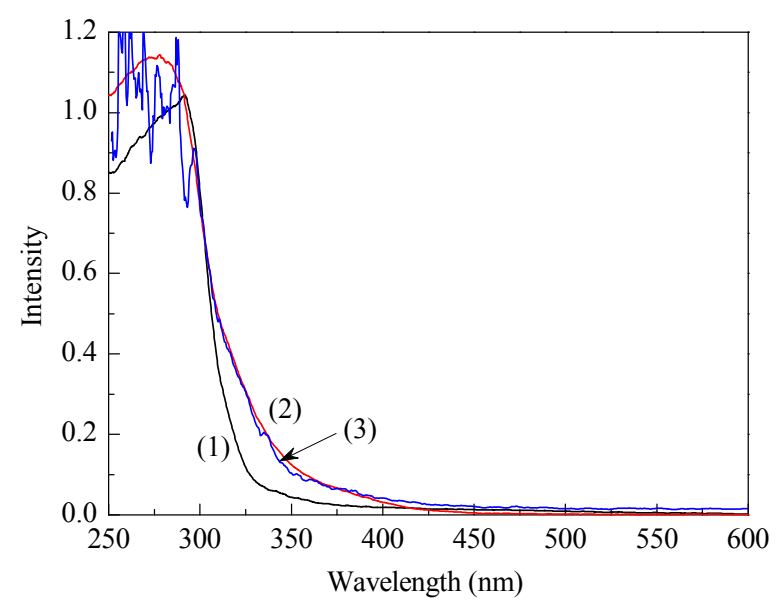

Fig. 4. UV-Vis diffused reflectance spectra of $\mathrm{NaTaO}_{3}(1), \mathrm{V}-0.02 \mathrm{NaTaO}_{3}$ (2) and III-0.02 $\mathrm{NaTaO}_{3}(3)$. 


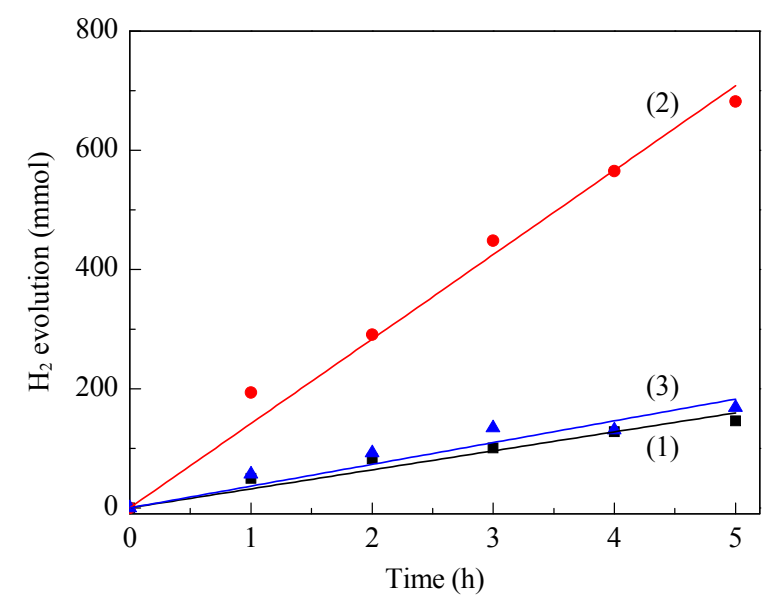

Fig. 5. Photocatalytic $\mathrm{H}_{2}$ evolution of $\mathrm{NaTaO}_{3}(1), \mathrm{V}-0.02 \mathrm{NaTaO}_{3}(2)$ and III-0.02 $\mathrm{NaTaO}_{3}(3)$.

that affects the photocatalytic activity. The Raman results indicated that $\mathrm{Bi}$ ion doping induced a distorted $\mathrm{B}-\mathrm{O}-\mathrm{B}$ bond from the bond angle of $180^{\circ}$, which was detrimental for charge carrier migration in $\mathrm{NaTaO}_{3}$. The $\mathrm{Bi}$ ion dopant induced the generation of a Na vacancy or an interstitial $\mathrm{O}$ in the lattice for charge compensation. These defects served as charge traps that promote the separation of the charge carriers and therefore the photocatalytic activity [27]. The separate actions of the positive and negative factors in the III-0.02 sample led to unchanged photocatalytic activity compared to pristine $\mathrm{NaTaO}_{3}$. For the $\mathrm{V}-0.02$ sample, it was found in the XPS data that both $\mathrm{Bi}^{5+}$ and $\mathrm{Bi}^{3+}$ ions were doped into the A-site. Compared to the III-0.02 sample, there were more defects in the V-0.02 sample that existed as high valence state $\mathrm{Bi}^{5+}$ ions in the lattice. That is, the separation efficiency of the charge carriers in the V-0.02 sample was higher than III-0.02. Therefore, a higher photocatalytic activity was obtained with $\mathrm{V}-0.02$. Our result indicated that the occupation by a high valence ion at the $\mathrm{A}$-site in the $\mathrm{ABO}_{3}$ per- ovskite structure was more favorable for the enhancement of photocatalytic activity.

\section{Conclusion}

Doping of $\mathrm{Bi}$ ion into $\mathrm{NaTaO}_{3}$ extended the light response to the visible light region. At the same time, it induced a distorted Ta-O-Ta bond and the generation of defects in the lattice, which influenced the charge carrier migration. $\mathrm{Bi}^{3+}$ substitution for Na did not increase the photocatalytic activity as expected. On the other hand, the occupancy by high valence state $\mathrm{Bi}^{5+}$ at the A-site increased the photocatalytic activity. Our results indicated that the charge transfer process is the key factor for the enhancement of photocatalytic activity, and it was more important than the extending of the range of light response. It was proposed that increasing the defect amount by doping with a high valence state ion in the A-site of the perovskite structure is a strategy to promote the separation of the charge carriers and thus the enhancement of photocatalytic activity.

\section{References}

[1] Maeda K, Teramura K, Lu D L, Takata T, Saito N, Inoue Y, Domen K. Nature, 2006, 440: 295

[2] Kang H W, Kim E J, Park S B. Int J Photoenergy, 2008, Article ID 519643

[3] Kato H, Kobayashi H, Kudo A.J Phys Chem B, 2002, 106: 12441

[4] Ishihara T, Nishiguchi H, Fukamachi K, Takita Y. J Phys Chem B, 1999, 103: 1

[5] Mizoguchi H, Ueda K, Orita M, Moon S C, Kajihara K, Hirano M, Hosono H. Mater Res Bull, 2002, 37: 2401

[6] Ouyang S X, Tong H, Umezawa N, Cao J Y, Li P, Bi Y P, Zhang Y J, Ye J H. J Am Chem Soc, 2012, 134: 1974

[7] Kudo A, Miseki Y. Chem Soc Rev, 2009, 38: 253

[8] Ditzig J, Liu H, Logan B E. Int J Hydrogen Energy, 2007, 32: 2296

[9] Kudo A, Niishiro R, Iwase A, Kato H. Chem Phys, 2007, 339: 104

[10] Kang H W, Lim S N, Park S B. Int J Hydrogen Energy, 2012, 37:

\section{Graphical Abstract}

Chin. J. Catal., 2015, 36: 969-974 doi: 10.1016/S1872-2067(15)60858-0

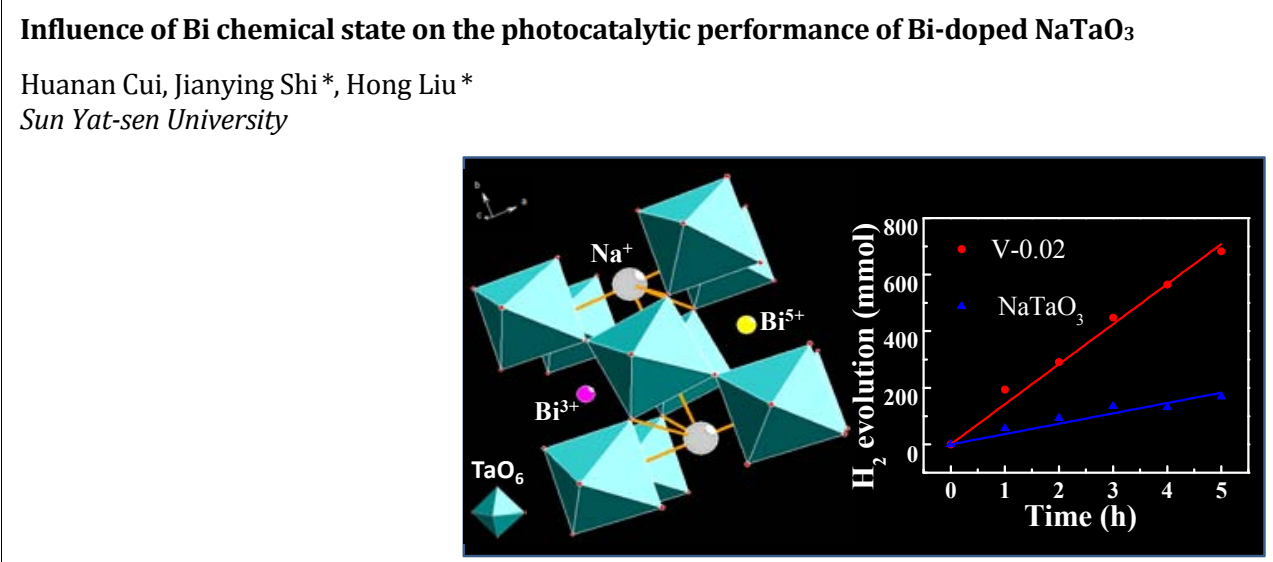

Doping of $\mathrm{Bi}^{5+}$ and $\mathrm{Bi}^{3+}$ in $\mathrm{NaTaO}_{3}$ substituting for $\mathrm{Na}^{+}$promoted the separation of charge carriers, and the photocatalytic for $\mathrm{H}_{2}$ evolution was enhanced. 
4026

[11] Gao Y, Su Y G, Meng Y, Wang S W, Jia Q Y, Wang X J. Integr Ferroelectr, 2011, 127: 106

[12] Liu Y L, Su Y G, Han H, Wang X J. J Nanosci Nanotechnol, 2013, 13: 853

[13] Husin H, Su W N, Chen H M, Pan C J, Chang S H, Rick J, Chuang W T, Sheu H S, Hwang B J. Green Chem, 2011, 13: 1745

[14] Hu C C, Lee Y L, Teng H S. J Mater Chem, 2011, 21: 3824

[15] Li X, Zang J L. Catal Commun, 2011, 12: 1380

[16] Iwase A, Kato H, Kudo A. ChemSusChem, 2009, 2: 873

[17] Kudo A, Kato H. Chem Phys Lett, 2000, 331: 373

[18] Zhou X, Shi J Y, Li C. J Phys Chem C, 2001, 115: 8305

[19] Kanhere P, Nisar J, Tang Y X, Pathak B, Ahuja R, Zheng J W, Chen Z. J Phys Chem C, 2012, 116: 22767

[20] Kang H W, Lim S N, Park S B, Park A H A. Int J Hydrogen Energy, 2013, 38: 6323

[21] Liu H M, Nakamura R, Nakato Y. J Electrochem Soc, 2005, 152: G856
[22] Konig J, Jancar B, Suvorov D. J Am Ceram Soc, 2007, 90: 3621

[23] Wang X J, Bai H L, Meng Y, Zhao Y H, Tang C H, Gao Y. J Nanosci Nanotechnol, 2010, 10: 1788

[24] Kanhere P D, Zheng J W, Chen Z. J Phys Chem C, 2011, 115: 11846

[25] Li Z G, Wang Y X, Liu J W, Chen G, Li Y X, Zhou C. Int J Hydrogen Energy, 2009, 34: 147

[26] Shi J Y, Chen T, Zhou G H, Feng Z C, Ying P L, Li C. Chem J Chin Univ (石建英, 陈涛, 周国华, 冯兆池, 应品良, 李灿. 高等学校化学学 报), 2007, 28: 692

[27] Shi J Y, Cui H N, Liang Z X, Lu X H, Tong Y X, Su C Y, Liu H. Energy Environ Sci, 2011, 4: 466

[28] Perry C H, Tornberg N E. Phys Rev, 1969, 183: 595

[29] Hu C C, Teng H. Appl Catal A, 2007, 331: 44

[30] Sidorov N V, Palatnikov M N, Mel'nik N N, Kalinnikov V T. J Appl Spectroscopy, 2000, 67: 259

[31] Reddy K H, Martha S, Parida K M. RSC Adv, 2012, 2: 9423

[32] Shi R, Lin J, Wang Y J, Xu J, Zhu Y F. J Phys Chem C, 2010, 114: 6472

\title{
$\mathrm{Bi}$ 掺杂 $\mathrm{NaTaO}_{3}$ 中 $\mathrm{Bi}$ 的化学价态对其光催化性能的影响
}

\author{
崔华楠，石建英"，刘 鸿\# \\ 中山大学化学与化学工程学院, 环境与能源化学广东普通高校重点实验室, 广东广州510275
}

\begin{abstract}
摘要: 分别采用 $\mathrm{NaBiO}_{3}$ 和 $\mathrm{Bi}\left(\mathrm{NO}_{3}\right)_{3}$ 为 $\mathrm{Bi}$ 源制备了 $\mathrm{Bi}$ 掺杂 $\mathrm{NaTaO}_{3}$ 光催化剂, 研究了 $\mathrm{Bi}$ 离子的价态对 $\mathrm{NaTaO}_{3}$ 光催化分解水制氢性能 的影响. 采用X射线衍射(XRD)、拉曼光谱、X射线光电子能谱(XPS)和紫外-可见吸收光谱研究了催化剂的晶体结构、Bi离子的化 学状态和催化剂的光学吸收性能. 以光催化分解水制氢反应研究了 $\mathrm{Bi}$ 离子掺杂 $\mathrm{NaTaO}_{3}$ 的催化性能. XRD结果表明, 对于两个不同 $\mathrm{Bi}$ 源掺杂的 $\mathrm{NaTaO}_{3}$ 样品, $\mathrm{Bi}$ 离子的掺杂没有改变催化剂的单斜相结构,但拉曼光谱证实 $\mathrm{Bi}$ 离子的掺杂致使 $\mathrm{Ta}-\mathrm{O}-\mathrm{Ta}$ 键角偏离了 $180^{\circ}$. XPS结果表明, 以 $\mathrm{Bi}\left(\mathrm{NO}_{3}\right)_{3}$ 为 $\mathrm{Bi}$ 源时, $\mathrm{Bi}$ 离子以 $\mathrm{Bi}^{3+}$ 掺杂于 $\mathrm{NaTaO}_{3}$ 的 $\mathrm{A}$ 位; 当以 $\mathrm{NaBiO}_{3}$ 为原料时, $\mathrm{Bi}^{3+}$ 和 $\mathrm{Bi}^{5+}$ 共掺杂于 $\mathrm{NaTaO}_{3}$ 的 $\mathrm{A}$ 位. 两种不同 $\mathrm{Bi}$ 源掺杂得到的样品在紫外-可见吸收光谱中给出了相似的光学吸收,但 $\mathrm{Bi}^{3+}$ 的掺杂对 $\mathrm{NaTaO}_{3}$ 光催化性能影响不大, 而 $\mathrm{Bi}^{3+}$ 和 $\mathrm{Bi}^{5+}$ 共掺杂大大提高了 $\mathrm{NaTaO}_{3}$ 的光解水制氢性能. $\mathrm{Bi}$ 离子取代 $\mathrm{Na}$ 离子在 $\mathrm{A}$ 位的掺杂, 在 $\mathrm{NaTaO}_{3}$ 结构中引入了能够促进载 流子分离的空位和缺陷; 与此同时, $\mathrm{Bi}$ 的掺杂导致 $\mathrm{Ta}-\mathrm{O}-\mathrm{Ta}$ 键角偏离 $180^{\circ}$ 而不利于载流子迁移. 对于 $\mathrm{Bi}^{3+}$ 掺杂的 $\mathrm{NaTaO}_{3}$ 样品, 这两 种作用相互抵消,使得其催化性能与 $\mathrm{NaTaO}_{3}$ 相比没有变化; 而 $\mathrm{Bi}^{3+}$ 和 $\mathrm{Bi}^{5+}$ 的共掺杂和高价态 $\mathrm{Bi}^{5+}$ 的掺杂引入了更多的空位和缺陷, 提高了光生电子-空穴的分离效率, 从而提高了光催化产氢性能. 研究表明, 光催化过程中载流子的迁移是影响催化性能的重要因 素,而在 $\mathrm{ABO}_{3}$ 钙钛矿结构的 $\mathrm{A}$ 位引入高价态离子是促进光生载流子分离的有效途径.
\end{abstract}

关键词: 光催化剂; 钽酸钠; Bi掺杂; 化学价态; 水分解

收稿日期: 2014-12-29. 接受日期: 2015-03-28. 出版日期: 2015-07-20.

*通讯联系人. 电话: (020)84114227; 电子信箱: shijying@mail.sysu.edu.cn

通讯联系人. 电话: (020)84115573; 传真: (020)84110927; 电子信箱: ceshliu@mail.sysu.edu.cn

基金来源：国家自然科学基金(21103235); 广州市科技计划(2013J4100110).

本文的英文电子版由Elsevier出版社在ScienceDirect上出版(http://www.sciencedirect.com/science/journal/18722067). 